\title{
FIFTIETH ANNUAL LIST OF PAPERS
}

\section{READ BEFORE THE AMERICAN MATHEMATICAL SOCIETY AND SUBSEQUENTLY}

PUBLISHED, INCLUDING REFERENCES TO THE PLACES OF PUBLICATION

Agnew, R. P. Some remarks on a paper entitled "General Tauberian theorems." Read April 27, 1940. Journal of the London Mathematical Society, vol. 15, no. 4 (Oct., 1940), pp. 242-246.

- Tauberian conditions. Read Feb. 24, 1940. Annals of Mathematics, (2), vol. 42, no. 1 (Jan., 1941), pp. 293-308.

- On methods of summability and mass functions determined by hypergeometric coefficients. Read Jan. 1, 1941. American Journal of Mathematics, vol. 63, no. 4 (Oct., 1941), pp. 705-708.

Agnew, R. P., and Kac, Mark. Translated functions and statistical independence. Read Feb. 24, 1940. This Bulletin, vol. 47, no. 2 (Feb., 1941), pp. 148-154.

Albert, G. E. A note on quasi-metric spaces. Read April 13, 1940. This Bulletin, vol. 47, no. 6 (June, 1941), pp. 479-482.

Alexandroff, Paul. General combinatorial topology. Read Sept. 12, 1940. Transactions of this Society, vol. 49, no. 1 (Jan., 1941), pp. 41-105.

Ambrose, Warren. Representation of ergodic flows. Read Jan.1, 1941. Annals of Mathematics, (2), vol. 42, no. 3 (July, 1941), pp. 723-739.

- Change of velocities in a continuous ergodic flow. Read Sept. 12, 1940. Duke Mathematical Journal, vol. 8, no. 3 (Sept., 1941), pp. 425-440.

Anderson, E. W. Statics of special types of homogeneous elastic slabs with variable thickness. Read Nov. 30, 1934. Dissertation, Iowa State College, 1933. 88 pp.

Aroian, L. A. Continued fractions for the incomplete beta function. Read Oct. 28, 1939. Annals of Mathematical Statistics, vol. 12, no. 2 (June, 1941), pp. 218-223.

Baker, G. A. Maximum likelihood estimation of the ratio of the components of nonhomogeneous populations. Read Nov. 23, 1940. Tôhoku Mathematical Journal, vol. 47, no. 2 (Sept., 1940), pp. 304-308.

- Fundamental distributions of errors for agricultural field trials. Read Nov. 23, 1940. National Mathematics Magazine, vol. 16, no. 1 (Oct., 1941), pp. 7-19.

Beckenbach, E. F. Functions having subharmonic logarithms. Read April 11, 1941. Duke Mathematical Journal, vol. 8, no. 2 (June, 1941), pp. 393-400.

- See Reade, Maxwell.

Bell, Clifford, A note on one-dimensional linear transformations. Read April 3, 1937. Tôhoku Mathematical Journal, vol. 48, no. 1 (May, 1941), pp. 55-59.

Bell, E. T. Transformed multiplicative diophantine equations. Read Dec. 2, 1939. Travaux de 1'Institut Mathématique de Tbilissi, vol. 8 (1940), pp. 1-21. Note on a certain type of diophantine system. Read April 6, 1940. This Bulletin, vol. 47, no. 2 (Feb., 1941), pp. 155-159.

- Selective equations. Read Nov. 23, 1940. Annals of Mathematics, (2), vol. 42, no. 4 (Oct., 1941), pp. 1029-1036.

Bell, P. O. On differential geometry intrinsically connected with a surface element of projective arc length. Read Sept. 7, 1939 and Dec. 30, 1940. Transactions of this Society, vol. 50, no. 3 (Nov., 1941), pp. 529-547.

Bergman, Stefan. On the surface integrals of functions of two complex variables. Read April 26, 1940. American Journal of Mathematics, vol. 63, no. 2 (April, 1941), pp. 295-318. 
The method of the minimum integral and analytic continuation of functions of complex variables. Read May 2, 1941. Proceedings of the National Academy of Sciences, vol. 27, no. 6 (June, 1941), pp. 328-332.

- On a generalized Green's function and certain of its applications. Read April 27, 1940. This Bulletin, vol. 47, no. 8 (Aug., 1941), pp. 651-661.

Berry, A. C. The accuracy of the Gaussian approximation to the sum of independent variates. Read Feb. 24, 1940. Transactions of this Society, vol. 49, no. 1 (Jan., 1941), pp. 122-136.

Betz, E. E. Accessibility and separation by simple closed curves. Read April 8, 1939. American Journal of Mathematics, vol. 63, no. 1 (Jan., 1941), pp. 127-135.

Biot, M. A. Equations of finite differences applied to torsional oscillations of crankshafts. Read Nov. 23, 1940. Journal of Applied Physics, vol. 11, no. 8 (Aug., 1940), pp. 530-537.

Birkhoff, Garrett. Metric foundations of geometry. Read Sept. 5, 1941. Proceedings of the National Academy of Sciences, vol. 27, no. 8 (Aug., 1941), pp. 402-406.

Black, Amos, and Davis, H. A. A birational transformation belonging to the complex of secants of a twisted cubic. Read Sept. 13, 1935. Proceedings of the West Virginia Academy of Science, vol. 14, no. 5 (Oct., 1940), pp. 84-86.

Blackall, C. J. On volume integral invariants of non-holonomic dynamical systems. Read Dec. 28, 1938. American Journal of Mathematics, vol. 63, no. 1 (Jan., 1941), pp. $155-168$.

Blake, Archie. Mathematical problems in seismology. Read Dec. 29, 1939. National Research Council, Transactions of the American Geophysical Union, (1940), pp. 1094-1113.

Blumenthal, L. M. A new concept of distance geometry with applications to spherical subsets. Read April 12, 1940. This Bulletin, vol. 47, no. 6 (June, 1941), pp. 435443.

Blumenthal, L. M., and Robinson, C. V. A new characterization of the straight line. Read Dec. 1, 1939. Reports of a Mathematical Colloquium (Notre Dame), (2), vol. 2 (1940), pp. 25-27.

Blumenthal, L. M., and Wahlin, G. E. On the spherical surface of smallest radius enclosing a bounded subset of $n$-dimensional euclidean space. Read Feb. 22, 1941. This Bulletin, vol. 47, no. 10 (Oct., 1941), pp. 771-777.

Boas, R. P. Functions with positive derivatives. Read Sept. 10, 1940. Duke Mathematical Journal, vol. 8, no. 1 (March, 1941), pp. 163-172.

- A general moment problem. Read Sept. 12, 1940. American Journal of Mathematics, vol. 63, no. 2 (April, 1941), pp. 361-370.

- A note on functions of exponential type. Read Feb. 22, 1941. This Bulletin, vol. 47, no. 10 (Oct., 1941), pp. 750-754.

Boas, R. P., and Widder, D. V. Functions with positive differences. Read Sept. 10, 1940. Duke Mathematical Journal, vol. 7 (Dec., 1940), pp. 496-503.

Bourgin, D. G. The Dirichlet problem for the damped wave equation. Read Dec. 26, 1939. Duke Mathematical Journal, vol. 7 (Dec., 1940), pp. 97-120.

Brauer, A. T. On a property of $k$ consecutive integers. Read Sept. 12, 1940. This Bulletin, vol. 47, no. 4 (April, 1941), pp. 328-331.

- On the density of the sum of sets of positive integers. II. Read Dec. 27, 1939. Annals of Mathematics, (2), vol. 42, no. 4 (Oct., 1941), pp. 959-988.

Brauer, Richard. On the Cartan invariants of groups of finite order. Read April 26, 1940. Annals of Mathematics, (2), vol. 42, no. 1 (Jan., 1941), pp. 53-61. 
- On sets of matrices with coefficients in a division ring. Read April 16, 1938. Transactions of this Society, vol. 49, no. 3 (May, 1941), pp. 502-548.

- On the connection between the ordinary and the modular characters of groups of finite order. Read April 11, 1941. Annals of Mathematics, (2), vol. 42, no. 4 (Oct., 1941), pp. 926-935.

- Investigations on group characters. Read Sept. 5, 1941. Annals of Mathematics, (2), vol. 42, no. 4 (Oct., 1941), pp. 936-958.

Brauer, Richard, and Coxeter, H. S. M. A generalization of theorems of Schönhardt and Mehmke on polytopes. Read Dec. 29, 1939. Transactions of the Royal Society of Canada, (3), Section III, vol. 34 (1940), pp. 29-34.

Brauer, Richard, and Nesbitt, C. J. On the modular characters of groups. Read Oct. 30, 1937. Annals of Mathematics, (2), vol. 42, no. 2 (April, 1941), pp. 556-590.

Brenner, J. L. The decomposition theorem for abelian groups. Read April 6, 1940. This Bulletin, vol. 47, no. 2 (Feb., 1941), pp. 116-117.

Brown, A. B. On transformation of multiple integrals. Read Feb. 24, 1940. American Mathematical Monthly, vol. 48, no. 1 (Jan., 1941), pp. 29-33.

Busemann, Herbert, and Mayer, Walther. On the foundations of calculus of variations. Read Sept. 12, 1940. Transactions of this Society, vol. 49, no. 2 (March, 1941), pp. 173-198.

Calkin, J. W. Symmetric transformations in Hilbert space. Read Dec. 30, 1938. Duke Mathematical Journal, vol. 7 (Dec., 1940), pp. 504-508.

- Abstract definite boundary value problems. Read Dec. 27, 1939. Proceedings of the National Academy of Sciences, vol. 26, no. 12 (Dec., 1940), pp. 708-712.

Two-sided ideals and congruences in the ring of bounded operators in Hilbert space. Read April 13, 1940. Annals of Mathematics, (2), vol. 42, no. 4 (Oct., 1941), pp. 839-873.

Callaghan, M. P. Generalized Frégier curves. Read Feb. 24, 1940. Revista de Ciencias, vol. 43, no. 435 (March, 1941), pp. 105-109.

Cameron, R. H. Analytic functions of absolutely convergent generalized trigonometric sums. Read Dec. 29, 1936. Duke Mathematical Journal, vol. 3, no. 4 (Dec., 1937), pp. $682-688$.

Cameron, R. H., and Martin, W. T. An unsymmetric Fubini theorem. Read Feb. 24, 1940. This Bulletin, vol. 47, no. 2 (Feb., 1941), pp. 121-125.

Carlitz, Leonard. An analogue of the Staudt-Clausen theorem. Read Sept. 12, 1940. Duke Mathematical Journal, vol. 7 (Dec., 1940), pp. 62-67.

- An analogue of the Bernoulli polynomials. Read May 3, 1941. Duke Mathematical Journal, vol. 8, no. 2 (June, 1941), pp. 405-412.

- Generalized Bernoulli and Euler numbers. Read Sept. 5, 1941. Duke Mathematical Journal, vol. 8, no. 3 (Sept., 1941), pp. 585-589.

Cassity, C. R. On the quartic del Pezzo surface. Read April 8, 1939. American Journal of Mathematics, vol. 63, no. 2 (April, 1941), pp. 256-262.

Churchill, R. V. A heat conduction problem introduced by C. J. Tranter. Read April 13, 1940. Philosophical Magazine, (7), vol. 31, no. 204 (Jan., 1941), pp. 81-87.

Clifford, A. H. Semigroups admitting relative inverses. Read Feb. 22, 1941. Annals of Mathematics, (2), vol. 42, no. 4 (Oct., 1941), pp. 1037-1049.

Clifford, A. H., and MacLane, Saunders. Factor-sets of a group in its abstract unit group. Read Feb. 22, 1941. Transactions of this Society, vol. 50, no. 3 (Nov., 1941), pp. 385-406.

Coburn, Nathaniel. A note on conformal geometry. Read Jan. 1, 1941. Proceedings of the National Academy of Sciences, vol. 27, no. 1 (Jan., 1941), pp. 57-60. 
- Conformal unitary spaces. Read Feb. 24, 1940. Transactions of this Society, vol. 50, no. 1 (July, 1941), pp. 26-39.

Unitary spaces with corresponding geodesics. Read Jan. 1, 1941. This Bulletin, vol. 47, no. 12 (Dec., 1941), pp. 901-910.

Copeland, A. H. Postulates for the theory of probability. Read April 9, 1937. American Journal of Mathematics, vol. 63, no. 4 (Oct., 1941), pp. 741-762.

- Fundamental concepts of the theory of probability. Read Nov. 27, 1937. American Mathematical Monthly, vol. 48, no. 8 (Oct., 1941), pp. 522-530.

Courant, Richard. Critical points and unstable minimal surfaces. Read Jan. 1, 1941. Proceedings of the National Academy of Sciences, vol. 27, no. 1 (Jan., 1941), pp. 51-57.

On a generalized form of Plateau's problem. Read April 27, 1940. Transactions of this Society, vol. 50, no. 1 (July, 1941), pp. 40-47.

Coxeter, H. S. M. The binary polyhedral groups, and other generalizations of the quaternion group. Read April 26, 1940. Duke Mathematical Journal, vol. 7 (Dec., 1940), pp. 367-379.

- See Brauer, Richard.

Crout, P. D. See Hildebrand, F. B.

Curry, H. B. A formalization of recursive arithmetic. Read April 26, 1940. American Journal of Mathematics, vol. 63, no. 2 (April, 1941), pp. 263-282.

- Some aspects of the problem of mathematical rigor. Read Oct. 26, 1940. This Bulletin, vol. 47, no. 4 (April, 1941), pp. 221-241.

$A$ revision of the fundamental rules of combinatory logic. Read Sept. 12, 1940. Journal of Symbolic Logic, vol. 6, no. 2 (June, 1941), pp. 41-53.

- Consistency and completeness of the theory of combinators. Read Sept. 12, 1940. Journal of Symbolic Logic, vol. 6, no. 2 (June, 1941), pp. 54-61.

- On the paradox of Kleene and Rosser. Read March 27, 1937. Transactions of this Society, vol. 50, no. 3 (Nov., 1941), pp. 454-516.

Curtiss, J. H. On the Jacobi series. Read Dec. 27, 1934, Jan. 2, 1936 and Oct. 30, 1937. Transactions of this Society, vol. 49, no. 3 (May, 1941), pp. 467-501.

- Necessary conditions in the theory of interpolation in the complex domain. Read Sept. 12, 1940. Annals of Mathematics, (2), vol. 42, no. 3 (July, 1941), pp. 634646.

- Riemann sums and the fundamental polynomials of Lagrange interpolation. Read Sept. 5, 1941. Duke Mathematical Journal, vol. 8, no. 3 (Sept., 1941), pp. 525-532.

Davis, H. A. See Black, Amos.

Day, M. M. Reflexive Banach spaces not isomorphic to uniformly convex spaces. Read Nov. 23, 1940. This Bulletin, vol. 47, no. 4 (April, 1941), pp. 313-317.

- Some more uniformly convex spaces. Read Nov. 23, 1940. This Bulletin, vol. 47, no. 6 (June, 1941), pp. 504-507.

DeCicco, J. J. See Kasner, Edward.

Dilworth, R. P. Ideals in Birkhoff lattices. Read Dec. 27, 1939. Transactions of this Society, vol. 49, no. 3 (May, 1941), pp. 325-353.

- The arithmetical theory of Birkhoff lattices. Read Oct. 28, 1939. Duke Mathematical Journal, vol. 8, no. 2 (June, 1941), pp. 286-299.

Dines, L. L. On the mapping of quadratic forms. Read Dec. 31, 1940. This Bulletin, vol. 47 , no. 6 (June, 1941), pp. 494-498.

Dodd, E. L. The problem of assigning a length to the cycle to be found in a simple moving average and in a double moving average of chance data. Read June 20, 1940. Econometrica, vol. 9, no. 1 (Jan., 1941), pp. 25-37. 
Douglas, Jesse. Solution of the inverse problem of the calculus of variations. Read Jan. 1, 1941. Transactions of this Society, vol. 50, no. 1 (July, 1941), pp. 71-128.

Dressel, F. G. The fundamental solution of the parabolic equation. Read Feb. 24, 1940. Duke Mathematical Journal, vol. 7 (Dec., 1940), pp. 186-203.

-A Stieltjes integral equation. Read Feb. 24, 1940. This Bulletin, vol. 47, no. 2 (Feb., 1941), pp. 79-83.

Dubisch, Roy. Non-cyclic algebras of degree four and exponent two with pure maximal subfields. Read April 13, 1940. This Bulletin, vol. 47, no. 2 (Feb., 1941), pp. 131133.

Duffin, R. J., and Schaeffer, A. C. Khintchine's problem in metric diophantine approximation. Read April 14, 1939. Duke Mathematical Journal, vol. 8, no. 2 (June, 1941), pp. 243-255.

- A refinement of the inequality of the brothers Markoff. Read Sept. 8, 1939. Transactions of this Society, vol. 50, no. 3 (Nov., 1941), pp. 517-528.

Dushnik, Ben, and Miller, E. W. Partially ordered sets. Read April 12 and Nov. 22, 1940. American Journal of Mathematics, vol. 63, no. 3 (July, 1941), pp. 600-610.

Dyer-Bennet, John. A note on partitions of the set of positive integers. Read Sept. 12, 1940. American Mathematical Monthly, vol. 48, no. 1 (Jan., 1941), pp. 15-17.

Eilenberg, Samuel. Ordered topological spaces. Read April 12, 1940. American Journal of Mathematics, vol. 63, no. 1 (Jan., 1941), pp. 39-45.

- An invariance theorem for subsets of $S^{n}$. Read Dec. 28, 1939. This Bulletin, vol. 47, no. 2 (Feb., 1941), pp. 73-75.

- Continuous mappings of infinite polyhedra. Read Dec. 29, 1939. Annals of Mathematics, (2), vol. 42, no. 2 (April, 1941), pp. 459-468.

- On spherical cycles. Read April 13, 1940. This Bulletin, vol. 47, no. 6 (June, 1941), pp. 432-434.

Eilenberg, Samuel, and MacLane, Saunders. Infinite cycles and homologies. Read Sept. 5, 1941. Proceedings of the National Academy of Sciences, vol. 27, no. 11 (Nov., 1941), pp. 535-539.

Eilenberg, Samuel, and Miller, E. W. Zero-dimensional families of sets. Read Dec.26, 1939. This Bulletin, vol. 47, no. 12 (Dec., 1941), pp. 921-923.

Engstrom, H. T. Polynomial substitutions. Read Feb. 29, 1936. American Journal of Mathematics, vol. 63, no. 2 (April, 1941), pp. 249-255.

Erdös, Paul, and Lehner, Joseph. The distribution of the number of summands in the partitions of a positive integer. Read Feb. 22, 1941. Duke Mathematical Journal, vol. 8, no. 2 (June, 1941), pp. 335-345.

Evans, G. C. Surfaces of minimum capacity. Read Jan. 1, 1941. Proceedings of the National Academy of Sciences, vol. 26, no. 11 (Nov., 1940), pp. 664-667.

—Continua of minimum capacity. Read Jan. 1, 1941. This Bulletin, vol. 47, no. 10 (Oct., 1941), pp. 717-733.

Feld, J. M. Counterpoints and associated cubic curves. Read Nov. 28, 1936. Scripta Mathematica, vol. 7 (1940), pp. 113-118.

Differential and integral invariants of plane curves and horn angles. Read Feb. 25, 1939. This Bulletin, vol. 47, no. 4 (April, 1941), pp. 318-327.

- The geometry of whirls and whirl-motions in space. Read Feb. 22, 1941. This Bulletin, vol. 47, no. 12 (Dec., 1941), pp. 927-933.

Feller, W. K. On the integral equation of renewal theory. Read Sept. 5, 1941. Annals of Mathematical Statistics, vol. 12, no. 3 (Sept., 1941), pp. 243-267.

Forsythe, G. E. Riesz summability methods of order $r$, for $\Re(r)<0$. Read Oct. 26, 1940. Duke Mathematical Journal, vol. 8, no. 2 (June, 1941), pp. 346-349. 
Foster, A. L. Natural systems: The structure of abstract monotone sequences. Read Dec. 2, 1939. Proceedings of the National Academy of Sciences, vol. 27, no. 6 (June, 1941), pp. 325-327.

Foster, M. C. Note on autopolar curves. Read Oct. 28, 1939. This Bulletin, vol. 47, no. 4 (April, 1941), pp. 247-253.

Frame, J. S. The double cosets of a finite group. Read Sept. 12, 1940. This Bulletin, vol. 47, no. 6 (June, 1941), pp. 458-467.

Friedman, Bernard. Fourier coefficients of bounded functions. Read Sept. 8, 1939. This Bulletin, vol. 47, no. 2 (Feb., 1941), pp. 84-92.

Friedrichs, K. O. On the minimum buckling load for spherical shells. Read May 3, 1941. Theodore von Kármán Anniversary Volume. Pasadena, California Institute of Technology, 1941, pp. 258-272.

Friedrichs, K. O., and Stoker, J. J. The non-linear boundary value problem of the buckled plate. Read Dec. 29, 1938. American Journal of Mathematics, vol. 63, no. 4 (Oct., 1941), pp. 839-888.

Frink, Orrin. Series expansions in linear vector space. Read Sept. 10, 1940. American Journal of Mathematics, vol. 63, no. 1 (Jan., 1941), pp. 87-100.

Garabedian, H. L., Hille, Einar, and Wall, H. S. Formulations of the Hausdorff inclusion problem. Read Sept. 12, 1940. Duke Mathematical Journal, vol. 8, no. 1 (March, 1941), pp. 193-213.

Geiringer, H. P. A generalization of the law of large numbers. Read Sept. 10, 1940. Annals of Mathematical Statistics, vol. 11, no. 4 (Dec., 1940), pp. 393-401.

Gelbart, Abe. On the growth properties of a function of two complex variables given by its power series expansion. Read Oct. 28 and Dec. 27, 1939. Transactions of this Society, vol. 49, no. 2 (March, 1941), pp. 199-210.

Girshick, M.A. Onthe sampling theory of roots of determinantal equations. Read March 26, 1937. Annals of Mathematical Statistics, vol. 10, no. 3 (Sept., 1939), pp. 203-224.

Goldstine, H. H. Linear functionals and integrals in abstract spaces. Read April 13, 1940. This Bulletin, vol. 47, no. 8 (Aug., 1941), pp. 615-620.

Graves, L. M. Some general approximation theorems. Read Sept. 8, 1939. Annals of Mathematics, (2), vol. 42, no. 1 (Jan., 1941), pp. 281-292.

Green, L. J. Twisted cubics associated with a space curve. II. Read Sept. 12, 1940. American Journal of Mathematics, vol. 63, no. 2 (April, 1941), pp. 352-360.

Greenwood, J. A. The first four moments of a general matching problem. Read March 26, 1937. Annals of Eugenics, vol. 10, no. 3 (Sept., 1940), pp. 290-292.

Greenwood, R. E. Hankel and other extensions of Dirichlet's series. Read Jan. 1, 1941. Annals of Mathematics, (2), vol. 42, no. 3 (July, 1941), pp. 778-805.

Hall, D. W., and Puckett, W. T. Conditions for the continuity of arc-preserving transformations. Read April 6, April 26 and Sept. 12, 1940. This Bulletin, vol. 47, no. 6 (June, 1941), pp. 468-475.

- Strongly arcwise connected spaces. Read Sept. 11, 1940. American Journal of Mathematics, vol. 63, no. 3 (July, 1941), pp. 554-562.

Hall, Marshall. A problem in partitions. Read Feb. 22, 1941. This Bulletin, vol. 47, no. 10 (Oct., 1941), pp. 804-807.

Hall, N. A. The solution of the trinomial equation in infinite series by the method of iteration. Read April 9, 1938. National Mathematics Magazine, vol. 15, no. 5 (Feb., 1941), pp. 219-229.

Halmos, P. R. The decomposition of measures. Read Feb. 22, 1941. Duke Mathematical Journal, vol. 8, no. 2 (June, 1941), pp. 386-392. 
- Statistics, set functions, and spectra. Read Feb. 24, 1940. Recueil Mathématique, (n.s.), vol. 9, no. 2 (1941), pp. 241-248.

Hamilton, H. J. On monotone and convex solutions of certain difference equations. Read Nov. 23, 1940. American Journal of Mathematics, vol. 63, no. 2 (April, 1941), pp. $427-434$.

Harrison, R. A. Cremona webs of surfaces in $S_{3}$ without base curves. Read Oct. 31, 1936. Dissertation, Cornell University, 1936. 3 pp.

Hedge, L. B. Moment problem for a bounded region. Read June 20, 1940. This Bulletin, vol. 47, no. 4 (April, 1941), pp. 282-285.

Heins, A. E. On the solution of partial difference equations. Read Dec. 30, 1938, April 14, 1939 and April 12, 1940. American Journal of Mathematics, vol. 63, no. 2 (April, 1941), pp. 435-442.

Heins, M. H. A note on a theorem of Rado concerning the $(1, m)$ conformal maps of a multiply-connected region into itself. Read April 27, 1940. This Bulletin, vol. 47, no. 2 (Feb., 1941), pp. 128-130.

- On the iteration of functions which are analytic and single-valued in a given multiplyconnected region. Read Dec. 27, 1939. American Journal of Mathematics, vol. 63, no. 2 (April, 1941), pp. 461-480.

- A generalization of the Aumann-Caratheodory "Starrheitssatz." Read May 2, 1941. Duke Mathematical Journal, vol. 8, no. 2 (June, 1941), pp. 312-316.

Hestenes, M. R. Extension of the range of a differentiable function. Read Jan. 1, 1941. Duke Mathematical Journal, vol. 8, no. 1 (March, 1941), pp. 183-192.

- An analogue of Green's theorem in the calculus of variations. Read April 15, 1939. Duke Mathematical Journal, vol. 8, no. 2 (June, 1941), pp. 300-311.

Hildebrand, F. B., and Crout, P. D. A least square procedure for solving integral equations by polynomial approximation. Read April 26, 1940. Journal of Mathematics and Physics, Massachusetts Institute of Technology, vol. 20, no. 3 (Aug., 1941), pp. 310-335.

Hille, Einar. A class of differential operators of infinite order, I. Read Sept. 10, 1940. Duke Mathematical Journal, vol. 7 (Dec., 1940), pp. 458-495.

- See Garabedian, H. L.

Holl, D. L. See Tripp, R. H.

Hotelling, Harold. Experimental determination of the maximum of a function. Read Sept. 10, 1940. Annals of Mathematical Statistics, vol. 12, no. 1 (March, 1941), pp. $20-45$.

Householder, A.S. A theory of steady-state activity in nerve-fiber networks. II: The simple circuit. Read April 11, 1941. Bulletin of Mathematical Biophysics, vol. 3, no. 3 (Sept., 1941), pp. 105-112.

Hsu, C. T. Samples from two bivariate normal populations. Read May 3, 1941. Annals of Mathematical Statistics, vol. 12, no. 3 (Sept., 1941), pp. 279-292.

Hua, Loo-keng. On Waring's problem for cubic polynomial summands. Read April 27, 1940. Science Reports of National Tsing Hua University, (A), vol. 4, nos. 2-3 (Sept., 1940), pp. 55-83.

Huntington, E. V. A survey of methods of apportionment in Congress. Read Feb. 24, 1940. U. S. Senate Document No. 304, Washington, D. C., 1940. 41 pp.

Hyers, D. H. On the stability of the linear functional equation. Read April 11, 1941. Proceedings of the National Academy of Sciences, vol. 27, no. 4 (April, 1941), pp. 222-224.

- A generalization of Fréchet's differential. Read Sept. 5, 1939. Proceedings of the National Academy of Sciences, vol. 27, no. 6 (June, 1941), pp. 315-316. 
See Michal, A. D.

Ingraham, M. H. Rational methods in matrix equations. Read April 14 and 15, 1939. This Bulletin, vol. 47, no. 2 (Feb., 1941), pp. 61-70.

Ingraham, M. H., and Trimble, H. C. On the matric equation $T A=B T+C$. Read April 9, 1938 and April 14, 1939. American Journal of Mathematics, vol. 63, no. 1 (Jan., 1941), pp. 9-28.

Isaacs, R. P. The finite differences of polygenic functions. Read Feb. 25, 1939. This Bulletin, vol. 47, no. 6 (June, 1941), pp. 444-448.

Jackson, Dunham. Note on certain orthogonal polynomials. Read Dec. 29, 1939. This Bulletin, vol. 47, no. 2 (Feb., 1941), pp. 96-102.

Jacobson, Nathan. Restricted Lie algebras of characteristic p. Read Sept. 12, 1940. Transactions of this Society, vol. 50, no. 1 (July, 1941), pp. 15-25.

James, H. M. Some applications of the Rayleigh-Ritz method to the theory of the structure of matter. Read May 3, 1941. This Bulletin, vol. 47, no. 12 (Dec., 1941), pp. 869884.

Jennings, S. A. The structure of the group ring of a p-group over a modular field. Read Oct. 28, 1939. Transactions of this Society, vol. 50, no. 1 (July, 1941), pp. 175185.

John, Fritz. The Dirichlet problem for a hyperbolic equation. Read April 12, 1940. American Journal of Mathematics, vol. 63, no. 1 (Jan., 1941), pp. 141-154.

Discontinuous convex solutions of difference equations. Read Sept. 12, 1940. This Bulletin, vol. 47, no. 4 (April, 1941), pp. 275-281.

Jones, F. B. Certain consequences of the Jordan curve theorem. Read Dec. 29, 1939. American Journal of Mathematics, vol. 63, no. 3 (July, 1941), pp. 531-544.

- A posyndetic continua and certain boundary problems. Read Sept. 12, 1940. American Journal of Mathematics, vol. 63, no. 3 (July, 1941), pp. 545-553.

- Monotonic collections of peripherally separable connected domains. Read Feb. 22, 1941. This Bulletin, vol. 47, no. 8 (Aug., 1941), pp. 661-664.

Kac, Mark. Convergence and divergence of non-harmonic gap series. Read Sept. 5, 1941. Duke Mathematical Journal, vol. 8, no. 3 (Sept., 1941), pp. 541-545.

Note on the distribution of values of the arithmetic function $d(m)$. Read May 2, 1941. This Bulletin, vol. 47, no. 10 (Oct., 1941), pp. 815-817. See Agnew, R. P.

Kakutani, Shizuo. A generalization of Brouwer's fixed point theorem. Read Feb. 22, 1941. Duke Mathematical Journal, vol. 8, no. 3 (Sept., 1941), pp. 457-459.

Kaplan, Wilfred. Regular curve-families filling the plane. I. Read Sept. 5, 1939. Duke Mathematical Journal, vol. 7 (Dec., 1940), pp. 154-185.

- Regular curve-families filling the plane. II. Read Sept. 5, 1939. Duke Mathematical Journal, vol. 8, no. 1 (March, 1941), pp. 11-46.

Kasner, Edward, and DeCicco, J. J. Families of curves conformally equivalent to circles. Read April 27, 1940. Transactions of this Society, vol. 49, no. 3 (May, 1941), pp. 378-391.

- Infinite groups generated by equilong transformations of period two. Read April 12, 1941. American Journal of Mathematics, vol. 63, no. 4 (Oct., 1941), pp. 709-725.

Kennedy, E. S. Exponential analogues of the Lambert series. Read Oct. 28, 1939. American Journal of Mathematics, vol. 63, no. 2 (April, 1941), pp. 443-460.

Ketchum, P. W. On the possible rate of growth of an analytic function. Read Dec. 29, 1936. Transactions of this Society, vol. 49, no. 2 (March, 1941), pp. 211-228.

Kiokemeister, Fred. The parastrophic criterion for the factorization of primes. Read April 12, 1941. Transactions of this Society, vol. 50, no. 1 (July, 1941), pp. 140159. 
Kober, H. On a theorem of Schur and on fractional integrals of purely imaginary order. Read Feb. 22, 1941. Transactions of this Society, vol. 50, no. 1 (July, 1941), pp. $160-174$.

Kolchin, E. R. On the exponents of differential ideals. Read Feb. 24, 1940. Annals of Mathematics, (2), vol. 42 , no. 3 (July, 1941), pp. 740-777.

Koopman, B. O. Intuitive probabilities and sequences. Read April 27, 1940. Annals of Mathematics, (2), vol. 42, no. 1 (Jan., 1941), pp. 169-187.

Krall, H. L. On derivatives of orthogonal polynomials. II. Read April 26, 1940. This Bulletin, vol. 47, no. 4 (April, 1941), pp. 261-264.

Lambert, W. D. The beginnings of mathematical geophysics in Great Britain. Read Dec. 29, 1939. National Research Council, Transactions of the American Geophysical Union, (1940), pp. 1068-1072.

Lancaster, O. E. Orthogonal polynomials defined by difference equations. Read Dec. 29, 1938. American Journal of Mathematics, vol. 63, no. 1 (Jan., 1941), pp. 185-207.

- Sequences defined by non-linear algebraic difference equations. Read April 16, 1938. Annals of Mathematics, (2), vol. 42, no. 1 (Jan., 1941), pp. 251-280.

LaSalle, J. P. Pseudo-normed linear spaces. Read Nov. 23, 1940. Duke Mathematical Journal, vol. 8, no. 1 (March, 1941), pp. 131-135.

Lehmer, D. H. The lattice points of an n-dimensional tetrahedron. Read Dec. 28, 1939. Duke Mathematical Journal, vol. 7 (Dec., 1940), pp. 341-353.

Lehner, Joseph. See Erdös, Paul.

Ling, D. P., and Recht, Leon. A theorem concerning the geodesics on a paraboloid of revolution. Read Feb. 24, 1940. This Bulletin, vol. 47, no. 12 (Dec., 1941), pp. 934-937.

Loomis, L. H. The decomposition of meromorphic functions into rational functions of univalent functions. Read Oct. 26, 1940. Transactions of this Society, vol. 50, no. 1 (July, 1941), pp. 1-14.

Lorch, E. R. The integral representation of weakly almost-periodic transformations in reflexive vector spaces. Read Dec. 29, 1939 and Oct. 26, 1940. Transactions of this Society, vol. 49, no. 1 (Jan., 1941), pp. 18-40.

Lowan, A. N. On the problem of wave-motion for the wedge of an angle. Read Oct. 28, 1939. Philosophical Magazine, (7), vol. 31, no. 208 (May, 1941), pp. 373-381.

Lubben, R. G. Concerning the decomposition and amalgamation of points, upper semicontinuous collections, and topological extensions. Read Sept. 9 and Dec. 28, 1937 and Sept. 6, 1938. Transactions of this Society, vol. 49, no. 3 (May, 1941), pp. $410-466$.

McEwen, W. H. On the degree of convergence of the derived series of Birkhoff. Read Sept. 6, 1938. American Journal of Mathematics, vol. 63, no. 1 (Jan., 1941), pp. 29-38.

McShane, E. J. Necessary conditions in generalized-curve problems of the calculus of variations. Read Sept. 8, 1939. Duke Mathematical Journal, vol. 7 (Dec., 1940), pp. 1-27.

- Existence theorems for Bolza problems in the calculus of variations. Read Sept. 8, 1939. Duke Mathematical Journal, vol. 7 (Dec., 1940), pp. 28-61.

- On the second variation in certain anormal problems of the calculus of variations. Read April 27, 1940. American Journal of Mathematics, vol. 63, no. 3 (July, 1941), pp. 516-530.

MacLane, Saunders. See Clifford, A. H.; Eilenberg, Samuel.

MacLane, Saunders, and Schilling, O. F. G. Normal algebraic number fields. Read April 27, 1940. Transactions of this Society, vol. 50, no. 2 (Sept., 1941), pp. 295-384.

MacNeille, H. M. A unified theory of integration. Read Dec. 29, 1938. Proceedings of the National Academy of Sciences, vol. 27, no. 1 (Jan., 1941), pp. 71-76. 
Maddaus, Ingo. On types of "weak" convergence in linear normed vector spaces. Read Sept. 8, 1939. Annals of Mathematics, (2), vol. 42, no. 1 (Jan., 1941), pp. 229-246.

Marcinkiewicz, J., and Zygmund, Antoni. On the behavior of trigonometric series and power series. Read Jan. 1, 1941. Transactions of this Society, vol. 50, no. 3 (Nov., 1941), pp. 407-453.

Martin, M. P. A sequence of limit tests for the convergence of series. Read April 27, 1940. This Bulletin, vol. 47, no. 6 (June, 1941), pp. 452-457.

Martin, R. S. Minimal positive harmonic functions. Read Oct. 26, 1940. Transactions of this Society, vol. 49, no. 1 (Jan., 1941), pp. 137-172.

Martin, Venable. Monotone transformations of non-compact two-dimensional manifolds. Read Dec. 30, 1938. Duke Mathematical Journal, vol. 8, no. 1 (March, 1941), pp. 136-153.

Martin, Venable, and Roberts, J. H. Two-to-one transformations on 2-manifolds. Read Feb. 24, 1940. Transactions of this Society, vol. 49, no. 1 (Jan., 1941), pp. 1-17.

Martin, W. T. See Cameron, R. H.

Mayer, Walther. See Busemann, Herbert.

Menger, Karl. On Cauchy's integral theorem in the real plane. Read Dec. 27, 1939. Proceedings of the National Academy of Sciences, vol. 25, no. 12 (Dec., 1939), pp. 621-625.

- On shortest polygonal approximations to a curve. Read April 13, 1940. Reports of a Mathematical Colloquium (Notre Dame), (2), vol. 2 (1940), pp. 33-38.

Mersman, W. A. Heat conduction in an infinite composite solid. Read April 5, 1941. This Bulletin, vol. 47, no. 12 (Dec., 1941), pp. 956-964.

Mewborn, A. B. See Michal, A. D.

Michal, A. D. Higher order differentials of functions with arguments and values in topological abelian groups. Read April 27, 1940. Revista de. Ciencias, vol. 43, no. 435 (March, 1941), pp. 155-176.

Michal, A. D., and Hyers, D. H. General differential geometries with coordinate interspace inner product. Read Nov. 26, 1938. Tôhoku Mathematical Journal, vol. 46, no. 2 (Feb., 1940), pp. 309-318.

Michal, A. D., and Mewborn, A. B. Abstract flat projective differential geometry. Read April 15, 1939. Acta Mathematica, vol. 72 (1940), pp. 259-281.

Michal, A. D., and Wyman, Max. Characterization of complex couple spaces. Read April 6, 1940. Annals of Mathematics, (2), vol. 42, no. 1 (Jan., 1941), pp. 247-250.

Miller, E. W. See Dushnik, Ben; Eilenberg, Samuel.

Mood, A. M. On the joint distribution of the medians in samples from a multivariate population. Read Sept. 2, 1941. Annals of Mathematical Statistics, vol. 12, no. 3 (Sept., 1941), pp. 268-278.

Morse, Marston, and Tompkins, C. B. Unstable minimal surfaces of higher topological structure. Read Dec. 27, 1939. Duke Mathematical Journal, vol. 8, no. 2 (June, 1941), pp. 350-375.

Murdoch, D. C. Structure of abelian quasi-groups. Read Oct. 28, 1939 and April 26, 1940. Transactions of this Society, vol. 49, no. 3 (May, 1941), pp. 392-409.

Murdoch, D. C., and Ore, Oystein. On generalized rings. Read Feb. 25, 1939. American Journal of Mathematics, vol. 63, no. 1 (Jan., 1941), pp. 73-86.

Myers, S. B. Riemannian manifolds with positive mean curvature. Read Dec. 31, 1940. Duke Mathematical Journal, vol. 8, no. 2 (June, 1941), pp. 401-404.

Nesbitt, C. J. See Brauer, Richard.

Neuhaus, Albert. Products of normal semi-fields. Read Sept. 8, 1939. Transactions of this Society, vol. 49, no. 1 (Jan., 1941), pp. 106-121. 
von Neumann, John, and Schoenberg, I. J. Fourier integrals and metric geometry. Read Sept. 1, 1936 and Dec. 29, 1938. Transactions of this Society, vol. 50, no. 2 (Sept., 1941), pp. 226-251.

Neyman, Jerzy. On a statistical problem arising in routine analyses and in sampling inspections of mass production. Read Nov. 23, 1940. Annals of Mathematical Statistics, vol. 12, no. 1 (March, 1941), pp. 46-76.

Niven, Ivan. Sums of $n$-th powers of quadratic integers. Read April 11, 1941. Duke Mathematical Journal, vol. 8, no. 3 (Sept., 1941), pp. 441-451.

Odle, J. W. Non-alternating and non-separating transformations modulo a family of sets. Read Nov. 23, 1940. Duke Mathematical Journal, vol. 8, no. 2 (June, 1941), pp. $256-268$.

Oldenburger, Rufus. The minimal number problem for binary forms. Read Dec. 30, 1940. Proceedings of the National Academy of Sciences, vol. 27, no. 3 (March, 1941), pp. 185-188.

- Recurrence of symbolic elements in dynamics. Read Dec. 28, 1939. This Bulletin, vol. 47, no. 4 (April, 1941), pp. 294-297.

Olds, C. D. On the representations, $N_{3}\left(n^{2}\right)$. Read April 6, 1940. This Bulletin, vol. 47 , no. 6 (June, 1941), pp. 499-503.

On the representations, $N_{7}\left(m^{2}\right)$. Read April 6, 1940. This Bulletin, vol. 47, no. 8 (Aug., 1941), pp. 624-628.

- On the number of representations of the square of an integer as the sum of three squares. Read April 6, 1940. American Journal of Mathematics, vol. 63, no. 4 (Oct., 1941), pp. 763-767.

Ore, Oystein. Remarks on structures and group relations. Read April 27, 1940. Beiblatt zur Vierteljahrsschrift der Naturforschenden Gesellschaft in Zürich, vol. 85, no. 32 (June, 1940), pp. 1-4.

- See Murdoch, D. C.

Oxtoby, J. C., and Ulam, S. M. Measure-preserving homeomorphisms and metrical transitivity. Read April 15, Oct. 29 and Dec. 30, 1938. Annals of Mathematics, (2), vol. 42, no. 4 (Oct., 1941), pp. 874-920.

Pall, Gordon. Simultaneous representation in a quadratic and linear form. Read Jan. 1, 1941. Duke Mathematical Journal, vol. 8, no. 1 (March, 1941), pp. 173-180.

Pate, R. S. Rings with multiple-valued operations. Read Arpil 11, 1941. Duke Mathematical Journal, vol. 8, no. 3 (Sept., 1941), pp. 506-517.

Paxson, E. W. Sur un espace fonctionnel abstrait. Read April 3, 1937. Revista de Ciencias, vol. 42, no. 434 (Dec., 1940), pp. 817-821.

— Les équations différentielles dans les espaces linéaires et topologiques. Read April 3, 1937. Revista de Ciencias, vol. 42, no. 434 (Dec., 1940), pp. 823-826.

Pepper, P. M. Concerning pseudo planar quintuples. Read April 26, 1940. Reports of a Mathematical Colloquium, (Notre Dame), (2), vol. 2 (1940), pp. 28-32.

Perlis, Samuel. Scalar extensions of algebras with exponent equal to index. Read April 12, 1940. This Bulletin, vol. 47, no. 8 (Aug., 1941), pp. 670-676.

Pólya, George. Sur l'existence de fonctions entières satisfaisant à certaines conditions linéaires. Read Sept. 12, 1940. Transactions of this Society, vol. 50, no. 1 (July, 1941), pp. 129-139.

Price, G. B. A class of monotone functions. Read Sept. 6, 1938. American Journal of Mathematics, vol. 61, no. 4 (Oct., 1939), pp. 941-946.

- A generalization of a metric space with applications to spaces whose elements are sets. Read Dec. 28, 1938. American Journal of Mathematics, vol. 63, no. 1 (Jan., 1941), pp. 46-56. 
Puckett, W. T. See Hall, D. W.

Purcell, E. J. Space Cremona transformations of order $m+n-1$. Read Sept. 10, 1940. This Bulletin, vol. 47, no. 4 (April, 1941), pp. 242-246.

Rademacher, H. A., and Whiteman, A. L. Theorems on Dedekind sums. Read April 27, 1940. American Journal of Mathematics, vol. 63, no. 2 (April, 1941), pp. 377-407.

Radó, Tibor. On a lemma of McShane. Read April 13, 1940. Annals of Mathematics, (2), vol. 42, no. 1 (Jan., 1941), pp. 73-83.

Radó, Tibor, and Reichelderfer, P. V. Note on an inequality of Steiner. Read April 13, 1940. This Bulletin, vol. 47, no. 2 (Feb., 1941), pp. 102-108.

- A theory of absolutely continuous transformations in the plane. Read April 15, 1939. Transactions of this Society, vol. 49, no. 2 (March, 1941), pp. 258-307.

Rainich, G. Y. Conditional invariants. Read April 10, 1937. Proceedings of the National Academy of Sciences, vol. 27, no. 7 (July, 1941), pp. 352-355.

- The Dirac equations and conditional invariants. Read Dec. 29, 1937. Proceedings of the National Academy of Sciences, vol. 27, no. 7 (July, 1941), pp. 355-358.

Rainville, E. D. A discrete group arising in the study of differential operators. Read April 15, 1939. American Journal of Mathematics, vol. 63, no. 1 (Jan., 1941), pp. 136-140.

Randels, W. C. On the absolute summability of Fourier series, III. Read Dec. 1, 1939. Duke Mathematical Journal, vol. 7 (Dec., 1940), pp. 204-207.

Randolph, J. F. Some properties of sets of the Cantor type. Read Sept. 10, 1940. Journal of the London Mathematical Society, vol. 16, no. 1 (Jan., 1941), pp. 38-42.

Reade, Maxwell, and Beckenbach, E. F. Generalizations to space of the Cauchy and Morera theorems. Read April 14, 1939. Transactions of this Society, vol. 49, no. 3 (May, 1941), pp. 354-377.

- An integral analogue of Laplace's equation. Read June 20, 1940. This Bulletin. vol. 47, no. 8 (Aug., 1941), pp. 633-640.

Recht, Leon. See Ling, D. P.

Reichelderfer, P. V. See Radó, Tibor.

Reid, W. T. Green's lemma and related results. Read April 12, 1941. American Journal of Mathematics, vol. 63, no. 3 (July, 1941), pp. 563-574.

Reissner, Eric. A new derivation of the equations for the deformation of elastic shells. Read Jan. 1, 1941. American Journal of Mathematics, vol. 63, no. 1 (Jan., 1941), pp. 177-184.

Riblet, H. J. Algebraic differential fields. Read Feb. 25, 1939. American Journal of Mathematics, vol. 63, no. 2 (April, 1941), pp. 339-346.

- A differential basis for algebraic differential fields. Read Feb. 24, 1940. American Journal of Mathematics, vol. 63, no. 2 (April, 1941), pp. 347-351.

Ritt, J. F. Complete difference ideals. Read Oct. 25, 1941. American Journal of Mathematics, vol. 63, no. 4 (Oct., 1941), pp. 681-690.

Robbins, H. E. On the classification of the mappings of a 2-complex. Read Sept. 6,1938. Transactions of this Society, vol. 49, no. 2 (March, 1941), pp. 308-324.

Roberts, J. H. A theorem on dimension. Read April 27, 1940. Duke Mathematical Journal, vol. 8, no. 3 (Sept., 1941), pp. 565-574.

- See Martin, Venable.

Robertson, M. S. The partial sums of multivalently star-like functions. Read May 3, 1941. Annals of Mathematics, (2), vol. 42, no. 4 (Oct., 1941), pp. 829-838.

Robinson, C. V. See Blumenthal, L. M.

Robinson, R. M. On the simultaneous approximation of two real numbers. Read Nov. 23, 1940. This Bulletin, vol. 47, no. 6 (June, 1941), pp. 512-513. 
Rosser, Barkley. Explicit bounds for some functions of prime numbers. Read Dec. 31, 1940. American Journal of Mathematics, vol. 63, no. 1 (Jan., 1941), pp. 211-232. An additional criterion for the first case of Fermat's last theorem. Read April 27, 1940. This Bulletin, vol. 47, no. 2 (Feb., 1941), pp. 109-110.

- A generalization of the euclidean algorithm to several dimensions. Read May 2, 1941. Proceedings of the National Academy of Sciences, vol. 27, no. 6 (June, 1941), pp. 309-311.

Salem, Raphaël. On absolute convergence of trigonometrical series. Read Feb. 22, 1941. Duke Mathematical Journal, vol. 8, no. 2 (June, 1941), pp. 317-334.

On some properties of symmetrical perfect sets. Read May 3, 1941. This Bulletin, vol. 47, no. 10 (Oct., 1941), pp. 820-828.

- On trigonometrical series whose coefficients do not tend to zero. Read May 2, 1941. This Bulletin, vol. 47, no. 12 (Dec., 1941), pp. 899-901.

Schaeffer, A. C. Inegualities of A. Markoff and S. Bernstein for polynomials and related functions. Read Nov. 23, 1940. This Bulletin, vol. 47, no. 8 (Aug., 1941), pp. 565579.

- See Duffin, R. J.

Schaeffer, A. C., and Szegö, Gabor. Inequalities for harmonic polynomials in two and three dimensions. Read April 6, 1940. Transactions of this Society, vol. 50, no. 2 (Sept., 1941), pp. 187-225.

Scherk, Peter. On real closed curves of order $n+1$ in projective n-space. Read Oct. 26, 1940. Proceedings of the National Academy of Sciences, vol. 27, no. 3 (March, 1941), pp. 181-182.

- Two estimates connected with the ( $\alpha, \beta)$-hypothesis. Read Feb. 24, 1940. Annals of Mathematics, (2), vol. 42, no. 2 (April, 1941), pp. 538-546.

Schilling, O. F. G. See MacLane, Saunders.

Schneckenburger, E. R. On 1-bounding monotonic transformations which are equivalent to homeomorphisms. Read Sept. 7, 1939. American Journal of Mathematics, vol. 63, no. 4 (Oct., 1941), pp. 768-776.

Schoenberg, I. J. See von Neumann, John.

Schwartz, Abraham. The Gauss-Codazzi-Ricci equations in Riemannian manifolds. Read Oct. 28, 1939. Journal of Mathematics and Physics, Massachusetts Institute of Technology, vol. 20, no. 1 (Jan., 1941), pp. 30-79.

Schwartz, H. M. Sequences of Stieltjes integrals. Read Jan. 1, 1941. This Bulletin, vol. 47, no. 12 (Dec., 1941), pp. 947-955.

Scott, W. T., and Wall, H. S. Value regions for continued fractions. Read Nov. 22, 1940. This Bulletin, vol. 47, no. 8 (Aug., 1941), pp. 580-585.

Sewell, W. E. See Walsh, J. L.

Sheffer, I. M. Some applications of certain polynomial classes. Read May 3, 1941. This Bulletin, vol. 47, no. 12 (Dec., 1941), pp. 885-898.

Sherman, Seymour. Some new properties of transfinite ordinals. Read Dec. 27, 1939. This Bulletin, vol. 47, no. 2 (Feb., 1941), pp. 111-116.

Shohat, J. A. The best polynomial approximation of functions possessing derivatives. Read May 2, 1941. Duke Mathematical Journal, vol. 8, no. 2 (June, 1941), pp. 376-385.

Sigley, D. T. $k$-set groups. Read Dec. 27, 1939. Annals of Mathematics, (2), vol. 41, no. 4 (Oct., 1940), pp. 767-770.

Simmons, H. A. Note on use of matrices in solving linear diophantine equations. Read April 12, 1941. Tôhoku Mathematical Journal, vol. 48, no. 1 (May, 1941), pp. 71-74. 
Slotnick, M. M. Gravimetric and seismic methods in petroleum exploratory geophysics. Read Dec. 29, 1939. National Research Council, Transactions of the American Geophysical Union, (1940), pp. 1081-1093.

Smiley, M. F. Measurability and modularity in the theory of lattices. Read Feb. 24, 1940. This Bulletin, vol. 47, no. 2 (Feb., 1941), pp. 76-78.

- Measurability and distributivity in the theory of lattices. Read Jan. 1, 1941. This Bulletin, vol. 47, no. 8 (Aug., 1941), pp. 604-611.

Sobczyk, Andrew. Projections in Minkowski and Banach spaces. Read Sept. 5, 1939. Duke Mathematical Journal, vol. 8, no. 1 (March, 1941), pp. 78-106.

Spencer, D. C. On mean one-valent functions. Read Dec. 27, 1939. Annals of Mathematics, (2), vol. 42, no. 3 (July, 1941), pp. 614-633.

On finitely mean valent functions. Read April 27, 1940. Proceedings of the London Mathematical Society, (2), vol. 47, no. 3 (Aug., 1941), pp. 201-211.

Stoker, J. J. See Friedrichs, K. O.

Sugar, Alvin. On a result of Hua for cubic polynomials. Read April 27, 1940. This Bulletin, vol. 47, no. 2 (Feb., 1941), pp. 164-165.

Swingle, P. M. Indecomposable connexes. Read Nov. 23, 1940. This Bulletin, vol. 47, no. 10 (Oct., 1941), pp. 796-803.

Synge, J. L. On the electromagnetic two-body problem. Read April 27, 1940. Proceedings of the Royal Society (A), vol. 177, no. 968 (Dec., 1940), pp. 118-139.

Szász, Otto. The jump of almost periodic functions and of Fourier integrals. Read Sept. 12, 1940. Duke Mathematical Journal, vol. 7 (Dec., 1940), pp. 360-366.

Szegö, Gabor. Power series with multiply monotonic sequences of coefficients. Read Sept. 12, 1940. Duke Mathematical Journal, vol. 8, no. 3 (Sept., 1941), pp. 559-564. See Schaeffer, A. C.

Thielman, H. P. On the convex solution of a certain functional equation. Read April 13, 1940. This Bulletin, vol. 47, no. 2 (Feb., 1941), pp. 118-120.

Thomas, J. M. Orderly differential systems. Read Dec. 31, 1940. Duke Mathematical Journal, vol. 7 (Dec., 1940), pp. 249-290.

Thrall, R. M. On projective equivalence of trilinear forms. Read April 14, 1939. Annals of Mathematics, (2), vol. 42, no. 2 (April, 1941), pp. 469-485.

- A note on a theorem by Witt. Read Sept. 5, 1939 and April 13, 1940. This Bulletin, vol. 47, no. 4 (April, 1941), pp. 303-308.

Tompkins, C. B. See Morse, Marston.

Tornheim, Leonard. Linear forms in function fields. Read April 13, 1940. This Bulletin, vol. 47, no. 2 (Feb., 1941), pp. 126-127.

Trimble, H. C. See Ingraham, M. H.

Tripp, R. H., and Holl, D. L. Stresses in an orthotropic elastic layer. Read Dec. 2, 1939. Iowa State College Journal of Science, vol. 14, no. 3 (April, 1940), pp. 295-303.

Trjitzinsky, W. J. Properties of growth for solutions of differential equations of dynamical type. Read Sept. 11, 1940. Transactions of this Society, vol. 50, no. 2 (Sept., 1941), pp. 252-294.

- Developments in the analytic theory of algebraic differential equations. Read April 27, 1940. Acta Mathematica, vol. 73 (1941), pp. 1-85.

Ulam, S. M. See Oxtoby, J. C.

Vandiver, H. S. On general methods for obtaining congruences involving Bernoulli numbers. Read Feb. 24, 1940. This Bulletin, vol. 46, no. 2 (Feb., 1940), pp. 121-123.

- The elements of a theory of abstract discrete semi-groups. Read Feb. 24, 1940. Beiblatt zur Vierteljahrsschrift der Naturforschenden Gesellschaft in Zürich, vol. 85, no. 32 (June, 1940), pp. 71-86. 
Wade, T. L. A note on subgeometries of projective geometry as the theories of tensors. Read April 27, 1940. This Bulletin, vol. 47, no. 6 (June, 1941), pp. 475-478.

Tensor algebra and Young's symmetry operators. Read Dec. 30, 1940. American Journal of Mathematics, vol. 63, no. 3 (July, 1941), pp. 645-657.

Wahlin, G. E. See Blumenthal, L. M.

Wald, Abraham. Asymptotically most powerful tests of statistical hypotheses. Read Feb. 24, 1940. Annals of Mathematical Statistics, vol. 12, no. 1 (March, 1941), pp. 119.

Wall, H. S. A class of functions bounded in the unit circle. Read April 27 and Oct. 26, 1940. Duke Mathematical Journal, vol. 7 (Dec., 1940), pp. 146-153.

- A continued fraction related to some partition formulas of Euler. Read June 20, 1940. American Mathematical Monthly, vol. 48, no. 2 (Feb., 1941), pp. 102-108.

- Some recent developments in the theory of continued fractions. Read Nov. 23, 1940. This Bulletin, vol. 47, no. 6 (June, 1941), pp. 405-423.

- See Garabedian, H. L.; Scott, W. T.

Wallace, A. D. Quasi-monotone transformations. Read Dec. 30, 1938 and Sept. 7, 1939. Duke Mathematical Journal, vol. 7 (Dec., 1940), pp. 136-145.

- Concerning relatively non-alternating transformations. Read Dec. 26, 1939. Proceedings of the National Academy of Sciences, vol. 27, no. 3 (March, 1941), pp. 182-185.

- Separation spaces. Read April 8, 1939 and April 26, 1940. Annals of Mathematics, (2), vol. 42, no. 3 (July, 1941), pp. 687-697.

- A fixed-point theorem for trees. Read May 3, 1941. This Bulletin, vol. 47, no. 10 (Oct., 1941), pp. 757-760.

Walsh, J. L., and Sewell, W. E. On the degree of polynomial approximation to analytic functions: Problem $\beta$. Read Sept. 12, 1940. Transactions of this Society, vol. 49, no. 2 (March, 1941), pp. 229-257.

Ward, J. A. A theory of analytic functions in linear associative algebras. Read April 14, 1939. Duke Mathematical Journal, vol. 7 (Dec., 1940), pp. 233-248.

Webster, M. S. Maximum of certain fundamental Lagrange interpolation polynomials. Read April 13, 1940. This Bulletin, vol. 47, no. 2 (Feb., 1941), pp. 71-73.

Weinstein, Alexander. On the decomposition of a Hilbert space by its harmonic subspace. Read Feb. 22, 1941. American Journal of Mathematics, vol. 63, no. 3 (July, 1941), pp. 615-618.

Weisner, Louis. Moduli of the roots of polynomials and power series. Read April 27, 1940. American Mathematical Monthly, vol. 48, no. 1 (Jan., 1941), pp. 33-36.

- Powers series the roots of whose partial sums lie in a sector. Read April 27, 1940. This Bulletin, vol. 47, no. 2 (Feb., 1941), pp. 160-163.

Wernick, William. Functional dependence in the calculus of propositions. Read Oct. 26, 1940. American Mathematical Monthly, vol. 47, no. 9 (Nov., 1940), pp. 602-605.

Western, D. W. An extension of the Laurent expansion. Read April 27, 1940. American Mathematical Monthly, vol. 48, no. 7 (Aug.-Sept., 1941), pp. 444-450.

Weyl, F. J. Analytic curves. Read April 26, 1940. Annals of Mathematics, (2), vol. 42, no. 2 (April, 1941), pp. 371-408.

Whiteman, A. L. Additive prime number theory in real quadratic fields. Read Feb. 24, 1940. Duke Mathematical Journal, vol. 7 (Dec., 1940), pp. 208-232.

- See Rademacher, H. A.

Whitman, P. M. Free lattices. Read Sept. 5, 1939. Annals of Mathematics, (2), vol. 42, no. 1 (Jan., 1941), pp. 325-330. 
Whitney, Hassler. On regular families of curves. Read April 27, 1940. This Bulletin, vol. 47, no. 2 (Feb., 1941), pp. 145-147.

Widder, D. V. See Boas, R. P.

Wilcox, L. R. A topology for semi-modular lattices. Read Sept. 10, 1940. Duke Mathematical Journal, vol. 8, no. 2 (June, 1941), pp. 273-285.

Wilder, R. L. Decompositions of compact metric spaces. Read Sept. 10, 1937. American Journal of Mathematics, vol. 63, no. 4 (Oct., 1941), pp. 691-697.

Wong, Y. K. On biorthogonal matrices. Read June 20, 1940. This Bulletin, vol. 47, no. 6 (June, 1941), pp. 424-431.

Wyman, Max. See Michal, A. D.

Youngs, J. W. T. Arc-spaces. Read Sept. 8, 1939. Duke Mathematical Journal, vol. 7 (Dec., 1940), pp. 68-84.

Zariski, Oscar. Pencils on an algebraic variety and a new proof of a theorem of Bertini. Read Jan. 1, 1941. Transactions of this Society, vol. 50, no. 1 (July, 1941), pp. $48-70$.

Zygmund, Antoni. See Marcinkiewicz, J. 